\title{
Legal Consequences Of Truth Ppat Deed Content, Price Transactions And Date Of Tax Deed After The Enactment Validation In The Boyolali District
}

\begin{abstract}
Istiningsih ${ }^{1}$ and Amin Purnawan ${ }^{2}$
Abstract. The purpose of this study was to identify and analyze: 1) The verification and validation of the contents of the deed tax on PPAT, the price of the transaction and date of the deed PPAT in Boyolali. 2) Obstacles and solutions in the implementation process of verification and validation of tax. 3) The legal consequences of the truth of the PPAT deed, the price of the transaction and date of certificate validation of PPAT following the introduction of the tax in Boyolali.

The approach method in this research is juridical empirical research that emphasizes the behavior of individuals or communities in connection with the law. The data used are primary and secondary data obtained through interviews and literature, methods of analysis with descriptive and qualitative analilis.

Results of the research results can be concluded: 1 ) The verification and validation performed Income Tax Office (KPP) Boyolali while BPHTB conducted by the Department of Revenue Management and Asset Finance (DPPKAD) Boyolali. Validation includes the documents and the truth value of the transaction. Clear relation, the transaction value greatly affects the nominal income tax paid to the state. In making the PPAT AJB have to wait for the process validation and manufacturing of Sale and Purchase Agreements can not be specified price and date of the transaction. 2) Barriers due to the use of the transaction value as the basis for calculating BPHTB This has often led to problems in the field, because it is not uncommon transactions submitted by the taxpayer is not considered suitable by the taxman, so it is not uncommon to tax officials in the process of verification / validation, requesting that the transaction value changed and adapted according to the assessment of tax officials. 3) In making the PPAT deed lists the consequences of the transaction price and the date of the deed made and signed. This problem occurs on the inclusion of the transaction price and the date made after the validation is complete, and the parties have been facing the PPAT in early before the validation is performed. Inclusion of the transaction price and date of the deed at the time the parties may face different from the transaction price and the stairs after the validation process. PPAT in this case makes statements that do not fit can be subjected to verbal warning, written, suspension, dismissal with respect and disrespect.

Keywords: Transfer of rights; PPAT; Taxes.
\end{abstract}

\section{Introduction}

Tenure is essentially a reflection of mankind's view of himself as a man in relation to the ground. Man's relationship with the land raises the authority and responsibility for the welfare of yourself and others. So should the use of the function of the earth and water, as well as the natural riches contained therein is aimed to achieve the greatest prosperity of all the people of Indonesia. As in article 33, paragraph 3 of the 1945

\footnotetext{
1 Master Notary Law Student, Sultan Agung Islamic University Semarang email aleaaza675@gmail.com

${ }^{2}$ Faculty of Law Universitas Islam Sultan Agung
} 
Constitution which reads that the land and water and natural resources contained in it are controlled by the state and used for the greatest prosperity of the people. ${ }^{3}$

Ownership of land is the birthright of every citizen of Indonesia stipulated in the Law on the basis of the Republic of Indonesia in 1945, in particular article 28 letter (h), which states that everyone has the right to have private property rights and property rights should not be taken over arbitrarily by anyone. The state guarantees the right of citizens to have a right to private property including land. The rights to land have described an individual's right to property, to be registered in the land registry. In the system of registration of land rights, recordation of the deed describes a detailed summary of the ownership of property and amendments there to, or any other transaction that affects a property. ${ }^{4}$

The interference of the Land Deed Official (PPAT) and the office of the Land of the transitions of land rights, guarantees that the registered name of the person who actually has the right without closing the actual chance to those who deserve to still be able to defend him. In a sense BAL registration is not interpreted in a positive system, but must be associated with the Law itself. ${ }^{5}$ Under PP 24 of 1997, the transition of land and objects on it should be done with the PPAT deed. The transfer of land from the owners to the recipient along with the submission of a juridical (Juridische of deeds), a submission must meet the formality of law, including eligibility, made through the established procedure, using a document created by / before PPAT. ${ }^{6}$

In Boyolali, any acquisition of land and / or buildings, require the parties to pay PJAK. For the acquisition of rights that occur through the purchase, the tax imposed on the two sides both sellers and buyers. The seller subject to income tax (VAT) and to the buyer subject to Tax on Acquisition of Land and Building (BPHTB) which amount is calculated based on the acquisition cost of the rights or Earned Value of Tax Object (NPOP). In everyday language, NPOP could also be interpreted as the value of the transaction or the value of a price agreement between sellers and buyers. As stipulated in the Regulation of Boyolali District No. 2 of 2011 that PPAT can not sign a deed of sale before submitting proof of payment of taxes. Likewise Land Board should not be issued a decree granting, vesting and transfer of land rights, if the application is not supported by sufficient evidence of tax payments that have been verified and validated.

Based on this background, lifted the title: "Legal Consequences Of Truth Ppat Deed Content, Price Transactions And Date Of Tax Deed After The Enactment Validation In The Boyolali District". This study tries to answer issues about the verification and validation of tax to the contents of the deed of PPAT, the price of the transaction and date of the deed PPAT in Boyolali, barriers and solutions in the implementation process of verification and validation of tax to the contents of the deed of PPAT, the price of the transaction and date of the deed PPAT in Boyolali, and the legal consequences of the truth PPAT deed contents, the price of the transaction and date of certificate validation PPAT following the introduction of the tax in Boyolali.

\footnotetext{
${ }^{3}$ Act of the Republic of Indonesia Number 5 of 1960 concerning provisions Agrarian

${ }^{4}$ Adrian Sutedi, 2012, Sertifikat Hak Atas Tanah, Pena Grafika, Jakarta, p.59

${ }^{5}$ Ibid, p. 103

${ }^{6}$ Ibid, p. 128
} 
The method used in this research is juridical empirical. Juridical empirical research that focuses on the behavior of individuals or communities in connection with the law. ${ }^{7}$ Specification of the research is descriptive. Primary data were collected by interview. Type of interview used in this study using a free guided interview, is a combination of free and guided interview. ${ }^{8}$ Secondary data is data obtained from a review of the literature or the review of the literature or library materials related to the problem or research materials that are often referred to legal materials. ${ }^{9}$ Analysis of the data used in this study is a qualitative analysis.

\section{Results and Discussion}

\subsection{Implementation Verification and Validation against Taxes of PPAT Deed, Price and Date Deed Transaction of PPAT in Boyolali}

Nowadays, the development community Boyolali and counted rapidly. People in Boyolali started much interested in buying and selling land or buildings. In the transition process rights to land and or building, the two taxes raised the UN, the Income Tax (VAT) for the seller and Customs Acquisition Rights to Land and Building (BPHTB) for the buyer. Income tax (VAT) is a tax due and must be paid by the seller and Customs Acquisition Rights to Land and Building (BPHTB) is payable and must be paid by the party acquiring the land and buildings before the deed or decree granting rights can be made and signed by the competent authority in this case the Land Deed official (PPAT). ${ }^{10}$ Proof of payment of taxes is one very important part in the process behind the name / transfer of rights to land and buildings in Indonesia, because PPAT forbidden to sign the deed of transfer of rights before the taxpayer settle the tax accordingly. ${ }^{11}$

It is stipulated in Article 29 paragraph (1) Regulation Boyolali District No. 2 of 2011 on Customs Peolehan Land and Building, which is a regulation established by Law No. 28 of 2009 on Local Taxes and Levies, stating that official land deed / notary can only sign the deed of transfer of land and / or buildings after the taxpayer submit proof of payment of taxes.

The parties are facing PPAT to a deed must submit proof of tax payment for further validated andverifiedby KPP and the Department of Revenue Management and Asset Finance (DPPKAD) Boyolali. Verification is done by the documents and related data to tax the truth contained in the Tax Payment Area (SSPD) BPHTB before BPHTB taxpayer makes payments owed by the Department of Revenue Management and Asset Finance (DPPKAD).

\footnotetext{
7 Soerjono Soekanto dan Sri Mamadji, 2009, Penelitian Hukum Normatif: Suatu Tinjauan Singkat, Raja Grafindo Persada, Jakarta, p.1

8 Ibid, p. 84

${ }^{9}$ Mukti Fajar dan Yulianto, 2010, Dualisme Penelitian Hukum Normatif dan Empiris, Pustaka Pelajar, Yogyakarta,p. 156

${ }^{10}$ Marihot Pahala Siahaan, 2005, Bea Perolehan Hak Atas Tanah Dan Bangunan Teori Dan Praktek, Edition I, Pbl. I, PT. Raja Grafindo Persada, Jakarta, p.160

11 Marihot Pahala Siahaan, 2010, Kompilasi Peraturan Dibidang BPHTB, Panduan Dalam Penyusunan Aturan Pelaksanaan Peraturan Daerah Tentang BPHTB, Graha Ilmu, Yogyakarta, p.7
} 
In the verification of DPPKAD Boyolali conduct a study of the Tax Payment Area (SSPD) that have been paid are submitted by the taxpayer or to diverfikasi and validated. In this verification the Department has determined the amount of the transaction value or the market value of its own so that when the verification turns SSPD transaction value is less than the value determined by the Office of the SSPD file will be returned to the taxpayer for repair as determined by the Department.

BPHTB tax object is the acquisition of land or buildings, ${ }^{12}$ while bases BPHTB Earned Value of Tax Object (NPOP), NPOP referred to in the transfer of rights through the sale and purchase is the price of the transaction. ${ }^{13}$ The transaction value is the value that an agreement between the parties conducting transactions, such as the buying and selling, is between the seller with buyers. The transaction value is what will be included in the content of PPAT Deed (Deed of Sale and Purchase). So that legal certainty in determining the value of the transaction succession the validity of a sale and purchase, in this case whether it is true that a good transaction value listed in the contents of the deed of sale or used as a basis BPHTB calculation is totally in keeping with the reality that has been approved or agreed to by the parties to a transaction.

Calculationtax BPHTB set forth in Article 8, 9 and Article 10 of Regulation Boyolali No. 2 of 2011 on the Tax on Acquisition of Land and Building, as follows:

(1) The amount is set at Rp.60.000.000,00 NPOPTKP (sixty million rupiahs) for each taxpayer.

(2) In terms of acquisition rights due to inheritance or testament grant received by the which is still in private family relationship in the lineage straight one degree up or down by one degree to the grantor a will, including the husband / wife, NPOPTKP set at Rp.300.000.000,00 (Three hundred million rupiah). ${ }^{14}$

Furthermore, in Article 9 stipulated that BPHTB Rates at 5\% (five percent). While on the way BPHTB calculation, namely:

(1) BPHTB principal amount shall be calculated by multiplying the tariff as referred to in Article 9 and the tax base as referred to in Article 7 paragraph (1) after deducting NPOPTKP as referred to in Article 8 paragraph (1) or subsection (2).

(2) In the case of NPOP referred to in Article 7 paragraph (2) is not known to or lower than the SVTO used in the imposition of land and building tax in the year of acquisition, the principal amount Withholding tax is calculated by multiplying the tariff as referred to in Article 9 with a SVTO land and building tax after deducting NPOPTKP as referred to in Article 8 paragraph (1) or subsection (2). ${ }^{15}$

For example, buying and selling in Boyolali with a transaction value of Rp.200.000.000,00. So great BPHTB tax to be paid is Rp.200.000.000,00 Rp.60.000.000,00 = Rp.140.000.000,00 x 5\% = Rp.7.000.000,00. In addition, the seller or assignor subject to income tax (VAT) on the sale of land and buildings at the rate of $5 \%$, so that the value of the acquisition Rp.200.000.000,00 then the seller will be subject to income tax amounting $=$ Rp.200,000,000 , $00 \times 5 \%=R p .10 .000 .000,00$.

\footnotetext{
12 Article 3 (1) of Boyolali District Regulation No. 2 of 2011 on the Tax on Acquisition of Land and Building

${ }^{13}$ Article 7 (2) of Boyolali District Regulation No. 2 of 2011 on the Tax on Acquisition of Land and Building

${ }^{14}$ Article 8 of Boyolali District Regulation No. 2 of 2011 on the Tax on Acquisition of Land and Building

${ }^{15}$ Article 10 of Boyolali District Regulation No. 2 of 2011 on the Tax on Acquisition of Land and Building
} 
In terms of verification and validation of tax BPHTB conducted by the Department of Finance Revenue and Asset Management Area (DPPKAD) Boyolali. Validation in the determination of the sale value of land per meter2 done through the process of land valuation. Assessment of land is done for a specific purpose and do certain time anyway, so the value of a given transaction only unfit for purpose andonthat date. Pricing in the validation usually approach market data or market price comparisons. By comparison of the market price, the value of land as an object to be assessed, calculated based on comparative analysis and adjustment. The forecast was made on a type of soil that has been known to the market price. ${ }^{16}$

Soil type of the comparison must contain criteria, a type in use, similar in certain circumstances, location and others. Comparison to the breadth of the land for example, when assessing the extent of land of $1,000 \mathrm{~m} 2$, the data should also have a comprehensive comparison which approximately $1,000 \mathrm{~m} 2$. The market price of the land has become kind of comparison in determining the price, which is known from the purchase and sale transactions or deals have been done on land adjacent to the land that will be determined diseputaran resale value. The data source market price of land become a benchmark in the validation or pricing information is usually obtained from the buyer or seller of the land, PPAT, the device regions and other sources that can be trusted by DPPKAD. ${ }^{17}$

DPPKAD to collect data on the identity of the tax object, for example the location of the land or buildings in question, the areas of land and / or buildings to be validated, the status of the rights of these objects, the type designation, the identity of the owner of the land and / or buildings are concerned, the status of the owners of land and buildings, the address of the subject of taxes and others concerned with the land and / or buildings into a sale and purchase transactions in the turnover of land and buildings. PPAT have to wait for the process validation and manufacturing of Sale and Purchase Agreements can not be listed price of the transaction including day, date and time. Numbering Sale and Purchase Agreements also will be made after the validation process is completed and the parties have been paid in taxes to be paid. Numbering in the Sale and Purchase Agreements constitute an identity of a document, in this case is the identity of a deed made by PPAT. ${ }^{18}$ The function of the numbering of the deed made by PPAT is for administrative purposes and to refer to the document on the specific legal interest, thus arranged in certain sequence numbering based on deed made by PPAT stored in the record books deed.

\subsection{Obstacles and Solutions in the Process of Verification and Validation Against Taxes of PPAT Deed, Price and Date Deed Transaction of PPAT in Boyolali}

In the verification and validation of tax in Boyolali certainly not in spite of obstacles. Such constraints due to the problems in the use of value transactions are used as the basis for calculating BPHTB. The provisions on base used as the basis for calculation is to use the value BPHTB transaction. The transaction value is the value that an

\footnotetext{
${ }^{16}$ Interview with Bp. Iwan, office staff Revenue Management Department of Finance and Asset (DPPKAD) Boyolali dated 18 April 2019

17 Ibid

${ }^{18}$ Ibid
} 
agreement between the parties that the transaction, as if in buying and selling, is between the seller with buyers. The transaction value is what will be included in the content of PPAT Deed (Deed of Sale and Purchase). So that legal certainty in determining the value of the transaction succession the legality of a selling bell.

Their use as the basis for calculating the transaction value BPHTB This has often led to problems in the field, because it is not rarely value of transactions submitted by the taxpayer is not considered suitable by tax officials, making it less taxing authority in the process of verification / validation, requesting that the transaction value changed and adapted according to the assessment revenue officer. This can happen because it is a natural thing, that people generally mild desirous that pay their taxes, so that the values listed in the deed and used as a basis BPHTB calculation does not match the actual reality that has approved by the parties. ${ }^{19}$

Vice versa, the tax man wants tax paid can be maximized. The use of transaction value in accordance with market prices tend to much higher than the Taxable Sale Value of Land and Building (UN NJOP), so that tax officials in determining the actual value of the transaction is not easy, in doing research for the correctness of the transaction value is used taxpayers to calculate BPHTB, agency officials must search for data and information or information from the various parties, which was not easy to obtain the exact value and guarantee the truth. In the event coercion and / or any action that imposes no transaction value in accordance with the reality that has been agreed by the parties, it will have an impact on the contents of the deed so that transactions can be null and void.

Validation for a set price per $\mathrm{m} 2$ usually there are obstacles, because many of the tax object must be assessed in the same time and date and the clerk who checked in the field is limited. In the validation of land and buildings is usually also see Land Value Zone (ZNT). ZNT is usually made on a few plots of land are estimated to have the same price. For example, there is land both located on the edge of the highway that used to house the store (shop) or land that both located in the village alley only accessible by motorcycle. ${ }^{20}$

Verification and validation of the evidence of payment is in the form of the Tax Payment Area (SSPD), which is performed by authorized service personnel, among others, to examine the truth of the value used to calculate BPHTB. Under the provisions of the law, that is the basis of calculation BPHTB transaction value. At issue is when the front of PPAT could have parties claimed that the value of the transaction does not correspond to reality, in the sense of a lower than actual, with the intention that the tax or its BPHTB light.

This is where that can lead to problems and obstacles in the further process of registration in the Land Office transition, because they have to wait for the validation process is completed by paying a drawback if there is less pay. The presence of obstacles in the registration process of the transition of the land rights are not in accordance with the expectations of society, which generally requires a fast and simple process. This is according to a statement that is our common hope, that the processing of the certificate after the full requirements can be completed within a reasonable

\footnotetext{
${ }^{19}$ Interview with Bp. Syamsuri, office staff Revenue Management Department of Finance and Asset (DPPKAD) Boyolali dated 18 April 2019

${ }^{20}$ Interview with Bp. Iwan office staff Revenue Management Department of Finance and Asset (DPPKAD) Boyolali dated 18 April 2019
} 
period. Services implementing agency professional land registration and transparency in working procedures and required fees, a requirement the successful implementation of land registration. ${ }^{21}$

Conditions of registration must wait for validation SSPD which sometimes takes a long time, in addition to the need to make changes and the amount of the payment transaction value when the value of the proposed BPHTB taxpayer does not correspond according to official calculations authorities. Under such conditions, it is in its development then the Letter to the National Land Agency of the Republic of Indonesia Number: 05 / SE / IV / 2013 on Registration of Land Rights, addressed to the Head Office of the Regional Land, in order to receive the registration of transfer of land without waiting for validation of the proof of payment BPHTB.

However, according DPPKAD BPHTB Boyolali because it is intended and into the original income provisions for pricing validation has become a necessity which is performed at the transfer of rights to land and buildings in Boyolali. Boyolali Land Office said validation needs to be done to meet the obligations of the seller and buyer in the process of registration of transfer of rights to land and buildings in Boyolali. Validation is done to look for the correctness of tax objects and calculations in accordance with the standards in accordance with their respective areas different from one another. ${ }^{22}$

\subsection{Legal Consequences of Truth Contents PPAT Deed, Deed Date Transaction Price and PPAT after the enactment of the Tax Validation in Boyolali}

Deed Land Deed Official (PPAT) is one source of data for maintenance of land registration data. Then it must be made such that it can be used as a solid foundation for the transfer of registration and the imposition of the relevant right. Therefore PPAT responsible for examining the conditions for the validity of the legal act concerned. Among other things match the data contained in the certificate with lists that exist in the Land Office. ${ }^{23}$ The value of transactions included in the content of PPAT Deed must comply with validated prices. So that is what determines the legal certainty in determining the validity of a sale and purchase, in this case whether it is true that a good transaction value listed in the contents of the deed of sale or used as a basis BPHTB calculation is totally in keeping with the reality that has been approved or agreed to by the parties to a transaction.

In making the PPAT deed has consequences in price included transaction and date on which the deed drawn up and signed. This problem occurs on the inclusion of the transaction price and the day, date, month, year and time that is done after the validation is complete, and the parties have been facing the PPAT in early before the validation is performed. Inclusion of the transaction price and date of the deed at the time the parties may face different from the transaction price and the stairs after the validation process. PPAT in this case makes statements that do not fit with the reality

\footnotetext{
${ }^{21}$ Maria S.W. Sumardjono, 2002, Kebijakan Pertanahan Antara Regulasi \& Implementasi, PT. Kompas Media Nusantara, Jakarta, p. 121

${ }^{22}$ Interview with Bp. Heri Sulistiyo, Boyolali District Land Office staff, 18 April 2019

${ }^{23}$ Adrian Sutedi, 2018, Peralihan Hak Atas Tanah dan Pendaftarannya, Cet.9, Sinar Grafika, Jakarta, p. 143
} 
of this is a dishonest act. Notary PPAT dishonest as may be subjected to verbal warning, written, suspension, dismissal with respect and disrespect.

Validation by DPPKAD violates the principle of secure, with the inclusion of the transaction price and dates to when the parties face to be unsafe, because if there are problems in the future such deed null and void. PPAT can be sued in court because, entering false information on the different inclusion on the side facing the current real written at the beginning of the deed. Validation violates the principle of affordable, land registration at the turn of land rights have become unaffordable because of frequent transfer of rights over land and the building is the result of inheritance. Most beneficiaries are people who can not afford financially. Validation by pricing this to be affordable for people who can not afford. Validation violates the principle of open, on registration process and transfer of rights to land and buildings are not fully open the back to the administration of the Regional Government. Pricing is in the validation of the regional policy, so that people do not know the information on the basis of pricing that is determined by DPPKAD. Policies in the validation of pricing as much as possible should be abolished as a condition for registration of land and buildings, because the validation burden society Boyolali District.

\section{Closing}

\subsection{Conclusion}

Based on the description and discussion above, the conclusion of researchers are as follows:

- The verification and validation in taxes to the contents of PPAT deed, the price of the transaction and date of the deed PPAT in Boyolali refers to Article 29 paragraph (1) Regulation Boyolali District No. 2 of 2011 that PPAT is forbidden to sign the deed if not the verification and validation of tax. Taxes Income taxes in question are and BPHTB. Income verification and validation is done at the Tax Office (KPP) Boyolali while BPHTB conducted by the Department of Revenue Management and Asset Finance (DPPKAD) Boyolali. Validation in the determination of the sale value of land each meter ${ }^{2}$ done through the process of land valuation. Validation includes the documents and the truth value of the transaction. Clear relation, the transaction value greatly affects the nominal income tax paid to the state. The transaction value is the value that an agreement between the parties to a transaction, such as when to buy and sell, is between buyers and sellers. The transaction value is what will be included in the content of PPAT Deed (Deed of Sale and Purchase). So that legal certainty in transactions helped determine the legitimacy of a purchase, in this case whether it is true that both transaction value included in the contents of the deed of sale or used as the basis for calculating BPHTB is completely consistent with the fact that has been approved or agreed to by the parties to a transaction. In making the PPAT AJB have to wait for the process validation and manufacturing of AJB has not been able to include the price of the transaction and date of the deed.

- Such constraints due to the problems in the use of transaction value is used as the basis for calculating BPHTB. Their use of the transaction value as the basis for calculating BPHTB This has often led to problems in the field, because it is not uncommon transactions submitted by the taxpayer is not considered suitable by the 
taxman, so it is not uncommon to tax officials in the process of verification / validation, requesting that the transaction value was changed and adjusted according to the assessment of tax officials. Validation for a set price each meter ${ }^{2}$ usually there are obstacles, because many of the tax object must be assessed in the same time and date and the clerk who checked in the field is limited.Due to the registration requirement must wait for validation SSPD which sometimes takes a long time, in addition to the need to make changes and the amount of the payment transaction value when the value of the proposed BPHTB taxpayer does not correspond according to official calculations authorities. In the event of difficulties in the validation process, the determination of price by the Regional Government of the parties will take care of themselves to local government. PPAT can not interfere in the process of validating the determination of price by DPPKAD the registration process transfer of rights over the buildings.

- The legal consequences of the truth of the PPAT deed, the price of the transaction and date of certificate validation PPAT following the introduction of the tax in Boyolali the value of transactions included in the content of PPAT Deed must comply with validated prices. So that is what determines the legal certainty in determining the validity of a sale and purchase. In making the PPAT deed has consequences in price included transaction and date on which the deed drawn up and signed. This problem occurs on the inclusion of the transaction price and the day, date, month, year and time that is done after the validation is complete, and the parties have been facing the PPAT in early before the validation is performed. Inclusion of the transaction price and date of the deed at the time the parties may face different from the transaction price and the stairs after the validation process. PPAT in this case makes statements that do not fit with the reality of this is a dishonest act. Notary PPAT dishonest as may be subjected to verbal warning, written, suspension, dismissal with respect and disrespect.

\subsection{Suggestion}

- Local Government should no longer use as the basis for calculating the transaction value BPHTB lead to uncertainty

- Need to increase the performance of the Association of Land Deed Official (IPPAT) Boyolali in dealing with the events in transition land rights.

\section{References}

\section{Books:}

[1] Achmad Tjahyono dan Triyono Wahyudi, 2004, Perpajakan Indonesia, PT. Raja Grafindo Persada, Jakarta

[2] Adrian Sutedi, 2012, Sertifikat Hak Atas Tanah, Pena Grafika, Jakarta

[3] Adrian Sutedi, 2018, Peralihan Hak Atas Tanah dan Pendaftarannya, Cet.9, Sinar Grafika, Jakarta

[4] Maria S.W. Sumardjono, 2002, Kebijakan Pertanahan Antara Regulasi \& Implementasi, PT. Kompas Media Nusantara, Jakarta

[5] Marihot Pahala Siahaan, 2005, Bea Perolehan Hak Atas Tanah Dan Bangunan Teori Dan Praktek, Edisi I ,Cet. I, PT. Raja Grafindo Persada, Jakarta 
[6] Marihot Pahala Siahaan, 2010, Kompilasi Peraturan Dibidang BPHTB, Panduan Dalam Penyusunan Aturan Pelaksanaan Peraturan Daerah Tentang BPHTB, Graha Ilmu, Yogyakarta

[7] Mokhammad Najih dan Soimin, 2012, Pengantar Hukum Indonesia, Setara Press, Malang

[8] Mukti Fajar dan Yulianto, 2010, Dualisme Penelitian Hukum Normatif dan Empiris, Pustaka Pelajar, Yogyakarta

[9] R.Santoso Brotodihardjo, 1991, Pengantar Ilmu Hukum Pajak, PT. Refika Aditama, Bandung

[10] Soerjono Soekanto dan Sri Mamadji, 2009, Penelitian Hukum Normatif: Suatu Tinjauan Singkat, Raja Grafindo Persada, Jakarta

[11] Supriadi, 2010, Hukum Agraria, Cetakan Keempat, Sinar Grafika, Jakarta

\section{Legislations:}

[1] Act Republic of Indonesia Number 5 of 1960 concerning provisions Agrarian

[2] Government regulation Number 34 of 2016 About Income Tax on Income from the Transfer of Rights to Land and / or buildings, and the Sale and Purchase Agreement on Land and / or buildings.

[3] Government Regulation No. 24 of 2016 concerning change on Government Regulation No. 37 of 1998 on the Regulation of Land Deed Official Position.

[4] Law of Boyolali district No. 2 of 2011 on the Tax on Acquisition of Land and Building

[5] Circular of the National Land Agency of the Republic of Indonesia Number 5 / SE / IV / 2013 date 10 April 2013 